\title{
Lab Based Analysis of Speed Control of DC Motor by Using Different Semiconductor Power Converters
}

\author{
Abdul Khalique Junejo, Ghullam Mustafa Bhutto, Munawar Ayaz Memon, Ehsan Ali Buriro \\ Department of Electrical Engineering, Quaid-E-Awam University of Engineering Sciences and Technology, \\ Nawabshah, Pakistan \\ Email: ak.junejo@gmail.com, gmu@quest.edu.pk, engr.mam@quest.edu.pk, ehsanaliburiro@gmail.com
}

Received 30 June 2015; accepted 16 July 2015; published 22 July 2015

Copyright (C) 2015 by authors and OALib.

This work is licensed under the Creative Commons Attribution International License (CC BY). http://creativecommons.org/licenses/by/4.0/

(c) (i) Open Access

\section{Abstract}

The flexible control of DC motor has been donated in the extensive use of DC motor in the era of industry, as the increasing usage of semiconductor power converter units. The speed control of DC motor is very sophisticated and specific. The speed of DC motor has been controlled by controlling the armature voltage by using thyristors. The armature voltage is controlled by using the different types of AC to DC semiconductor converters such as half wave converter, semi converter and full wave converter by using thyristor-diodes. This paper shows the experimental comparative analysis of the DC motor speed control by using the different power converter topologies performed at the Quaid-E-Awam University of Engineering Sciences and Technology, Nawabshah lab.

\section{Keywords}

AC/DC Convertors, DC Motor, Torque Speed Characteristics

Subject Areas: Electric Engineering

\section{Introduction}

The DC motors are widely used because of their simplicity in their control action. The smartness of the DC motor is its control up to the wide range. Dc Machine can be controlled by armature voltage control, armature voltage controlled by AC-DC converters [1]. There are several methods of speed control of the DC motor and the armature voltage control is one of the methods among these methods. AC-DC converter drives effects on the linearity of the torque-speed characteristics [2]. The armature voltage control of DC motor is performed by using various topological networks of power semiconductor converters such as controlled and uncontrolled rectifiers by using diodes and the thyristor [3]. The disadvantage of power converters is the discontinuity in current. Due 
to this property of the power converters, non-linearity will occur in the torque of DC motors. The non-linearity in the torque is unavoidable for large loads on motors. Nowadays, latest techniques are applied to control the discontinuity of current [4]. Different topology og power converter may be fabricated in single chip from semiconductor material for speed control of DC Machine [5]. Speed control of DC motor may be by using chopper which can give us better results of speed-torque characteristics [6]. Speed control of DC motor can be controlled by using P, PID and Fuzzy technique with power converters for better results [7]. An experimental setup is carried out in the Electrical Engineering Department of Quaid-E-Awam University of Sciences and technology (QUEST) laboratory. The Continuity and the linearity have been observed on DC motor by using semiconductor converters half wave converter, semi converter and full wave converter shown in following figures.

A single phase half wave thyristor based converter which is used to control the DC motor is shown in Figure 1. A single phase half wave controller is used for the DC motor up to its rating of $0.5 \mathrm{~kW}$. The average output voltage of single phase converter can be calculated from equation. It is half quadrant drive converter.

$$
V_{o}=\frac{V_{m}}{2 \pi}(1+\operatorname{Cos} \theta) \text { for } 0<\theta<\pi
$$

Single phase semi wave thyristor based converter is shown in Figure 2. This converter is used for the DC motor up to the rating of $15 \mathrm{~kW}$. The average output voltage of a single phase semi converter can be calculated from equation. It is one quadrant drive controller.

$$
V_{o}=\frac{V_{m}}{\pi}(1+\operatorname{Cos} \theta) \text { for } 0<\theta<\pi
$$

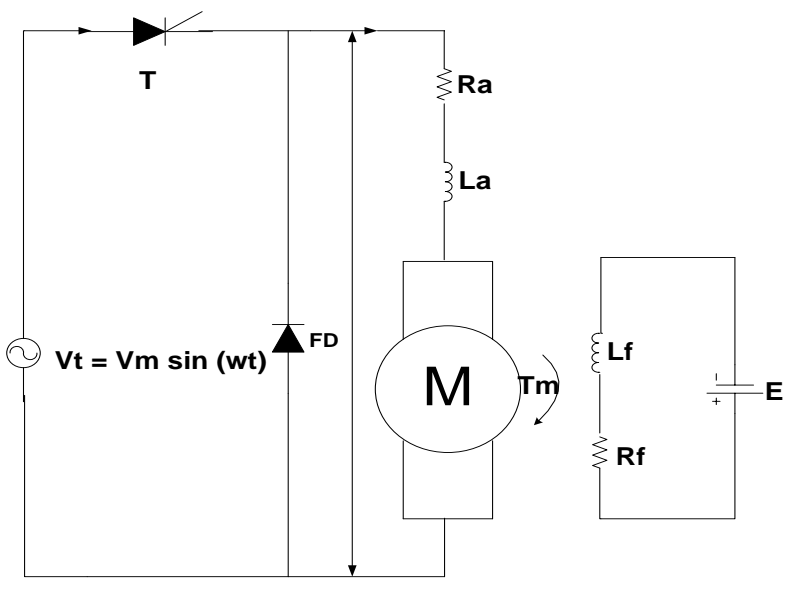

Figure 1. Single phase half wave converter drive.

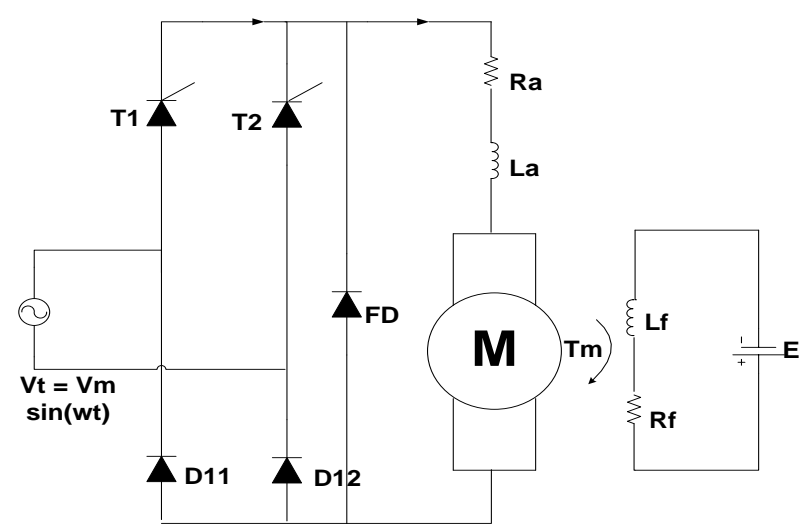

Figure 2. Single phase semi converter drive. 
A single phase full wave thyristor based converter is shown in Figure 3. This converter is used for the DC motor up to the rating of $15 \mathrm{~kW}$. The average output voltage of single phase full wave converter can be calculated from equation. It is two quadrant drive converter.

$$
V_{o}=\frac{2 V_{m}}{\pi}(1+\operatorname{Cos} \theta) \text { for } 0<\theta<\pi
$$

The armature voltage converters may be half, semi and full converter and works on positive and negative voltage from first quadrant to fourth quadrant.

\section{Modelling of DC Motor}

When a DC supply is applied to the armature of the dc motor with its field excited by a dc supply, torque is developed in the armature due to the contact between the axial current carrying conductors on the rotor and radial magnetic flux is produced by the stator. If $V$ is the applied voltage applied to the armature terminal of the motor, and $E$ is the internally developed rotational e.m.f. The resistance and inductance of the complete armature are represented by Ra and La as shown in Figure 4 [8].

Under driving conditions, the rotational e.m.f. E always opposes the applied voltage $V$, and for this reason it is referred to as "back emf" for current to be forced in to motor, $V$ must be greater than $E$, the armature circuit voltage equation being given by

$$
v=E+I_{a} R_{a}+L \frac{\mathrm{d} I_{a}}{\mathrm{~d} t}
$$

The last term in Equation (1) denotes the inductive voltage drop due to armature self-inductance. This voltage is proportional to rate of change of current, so under steady state conditions (i.e. when the current is constant), the term will be zero and can be overlooked. Under steady state-condition, the armature current $I$ is constant and Equation (1) simplifies to

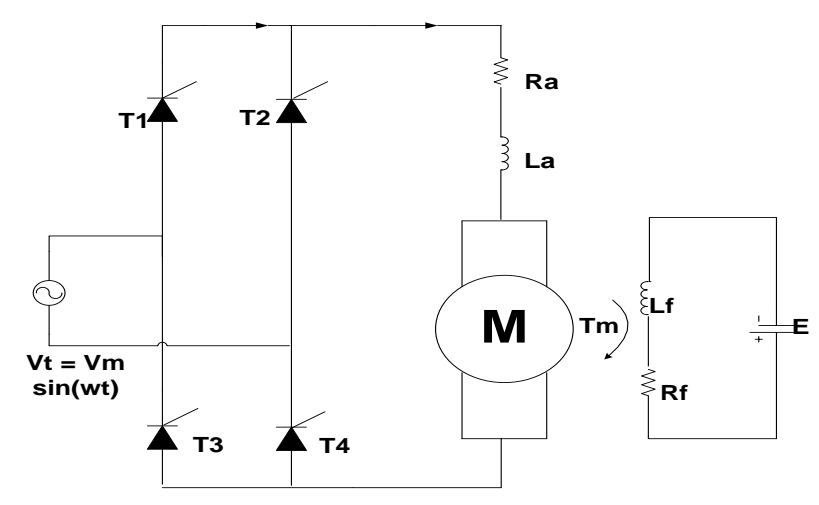

Figure 3. Single phase full wave converter drive.

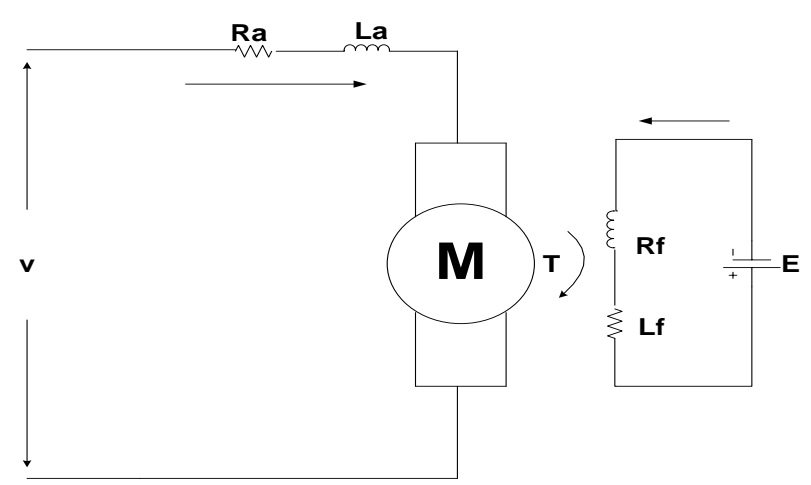

Figure 4. Equivalent circuit diagram of DC motor. 


$$
V=E+I_{a} R_{a}
$$

The motor back emf is given by

$$
E_{b}=\frac{\varnothing N Z}{60}\left(\frac{P}{A}\right) \text { Volts }
$$

where $\varnothing$ is flux per pole in webers

$Z$ is number of armature conductors.

$N$ is speed in rpm.

$A$ is number of parallel paths in armature.

Here $Z, P, A$ are fixed for a particular machine after wounded. Therefore for a given DC machine

$$
\begin{gathered}
E_{b}=\left(\frac{Z P}{60 A}\right) \varnothing N \text { volt } \\
E_{b}=K_{a} \varnothing N
\end{gathered}
$$

where $\frac{60}{2 \pi} \omega_{m}$, substitute in Equation (4)

$$
\begin{gathered}
E_{b}=\left(\frac{Z P}{60 A}\right) \varnothing\left(\frac{60}{2 \pi}\right) \omega_{m} \text { volts } \\
E_{b}=\left(\frac{Z P}{2 \pi A}\right) \varnothing \omega_{m}=\left(\frac{Z P}{2 \pi A}\right) \varnothing I_{a} \\
E_{b}=K_{a} \varnothing \omega_{m}
\end{gathered}
$$

The torque developed by armature is given by

$$
T_{a}=\frac{\varnothing Z I_{a}}{2 \pi}\left(\frac{P}{A}\right) N-m
$$

where,

$$
\begin{gathered}
K_{a}=(Z P / 2 \pi A) \\
T_{a}=K_{a} \varnothing I_{a}=T
\end{gathered}
$$

From expression (2)

$$
I_{a}=\left(\frac{V-E}{R_{a}}\right)
$$

Substituting Equation (10) in Equation (9), we get

$$
T_{a}=K_{a} \varnothing\left(\frac{V-E}{R_{a}}\right)
$$

Substituting Equation (9) in Equation (11), we get

$$
T_{a}=K_{a} \varnothing\left[\frac{V-K_{a} \varnothing \omega_{m}}{R_{a}}\right]
$$

Rearranging the above equations, we get

$$
\omega_{m}=\frac{V}{K_{a} \varnothing}-\frac{R_{a}}{\left(K_{a} \varnothing\right)^{2}} T_{a}
$$

The above expression gives the relationship between speed and torque for DC motors. Speed-current rela- 
tionship can be obtained if $\frac{T_{a}}{K_{a} \varnothing}$ in the expression (13) is replaced with $I_{a}$ (From Equation (9)) as given below

$$
\omega_{m}=\frac{V}{K_{a} \varnothing}-\frac{R_{a} I_{a}}{\left(K_{a} \varnothing\right)}
$$

Figure 5 shows the speed toque characteristics and speed current characteristics of DC motor when the armature and field voltage are kept constant. As seen from in the above equation part 2 the speed torque characteristics and speed current characteristic of separately excited or DC motor is given below,

$$
\begin{array}{r}
\omega_{m}=\frac{V}{\left(K_{a} \varnothing\right)^{2}} T_{a}=\omega_{0}-\Delta \\
\omega_{m}=\frac{V}{k_{a} \varnothing}-\frac{R_{a} I_{a}}{K_{a} \varnothing}=\omega_{0}-\Delta \omega
\end{array}
$$

where $\omega_{0}$ the no load is speed and $\Delta \omega$ is the speed drop. The no load speed is added where the torque and current are equal to zero. The speed drop is a function of load torque. From the above expression speed of separately excited DC motor or motor can be controlled by controlling the following quantities.

a) Resistance added to armature circuit.

When resistance is inserted in armature circuit, the speed drop $\Delta \omega$ increases and motor speed decreases.

b) Terminal voltage (Armature voltage).

Reducing the armature voltage $V$ of the motor reduces the motor speed.

c) Field Flux (or field voltage).

Reducing field voltage $V$ of the motor reduces the flux, and the motor speed increases.

Controlling Speed by regulating armature voltage

A common method of controlling speed is to adjust the armature voltage. This method is very efficient, stable and is simple to implement. The circuit diagram shown in Figure 1 gives the basic concept of this method. The only controlled variable is the armature voltage of the motor, which is represented as a modifiable voltage source. Based on Equation (9).

When armature voltage is reduced no load speed is also reduced, the armature voltage does not affect the speed drop $\Delta \omega$. The slope of speed torque and field flux, the armature voltage does not affect the speed drop $\Delta \omega$. The slope of speed torque characteristics is $\frac{R_{a}}{\left(K_{a} \varnothing\right)^{2}}$, which is independent of the armature voltage.

Therefor characteristics are shown as Figure 5. It is observed that the field voltage is Unchanged when the armature voltage varies [8].

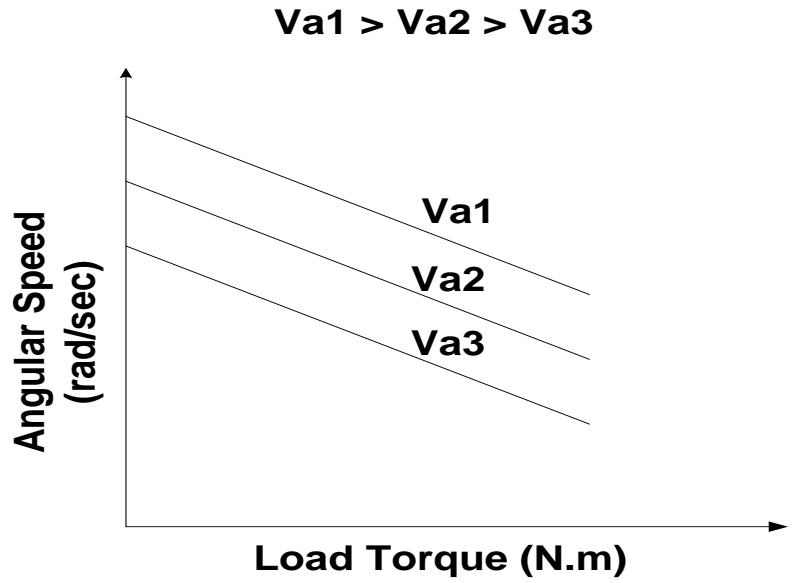

Figure 5. Speed-Torque characteristic of DC motor. 


\section{Lab Results and Discussions}

The speed control analysis of the DC motor by using different power converters such as half wave, semi converter and full wave converter. This analysis is purely based on the experimental analysis of power converters by applying different torques on the DC motor in QUEST University Nawabshah Sindh Pakistan laboratory. The applied torque changing from 0 to $2 \mathrm{Nm}$ (mechanical) load, to analyze the speed of the DC motor by using the different power converters, the model picture of DC motor with patching diagram shown in Figure 6 .

The results of the speed-torque characteristics of DC motor on the single phase half wave converter, semi converter and full wave converter shown in following Figure 7, Figure 9 and Figure 11. It has been observed in graphs that the linear and nonlinearity of armature current due to power converters. This non linearity in armature current effects on DC motor torque, whenever torque increases the speed of DC motor decreases as shown in following figures. It has been also observed that when torque of DC motor increasing the armature voltage decreases as shown in Tables 1-3. Armature current-voltage wave forms shown in Figure 8, Figure 10 and Figure 12, it is clearly shown in wave form of armature current that discontinuous of armature current cause high nonlinear torque on DC motor.

In Figure 7, speed-torque characteristics of DC motor shown by using the Table 1, when torque on DC motor increases the speed of DC motor decreases, also in Figure 8 wave forms of armaturevoltage and armature current is shown it is clear view of discontinuous in armature current due to this discontinuous of armature current will effect on linearity of DC motor torque.

In Figure 9, speed-torque characteristics of DC motor shown by using the Table 2, when torque on DC motor increases the speed of DC motor decreases, also in Figure $\mathbf{1 0}$ wave forms of armature voltage and armature current is shown it is clear view of discontinuous in armature current due to this discontinuous of armature cur-

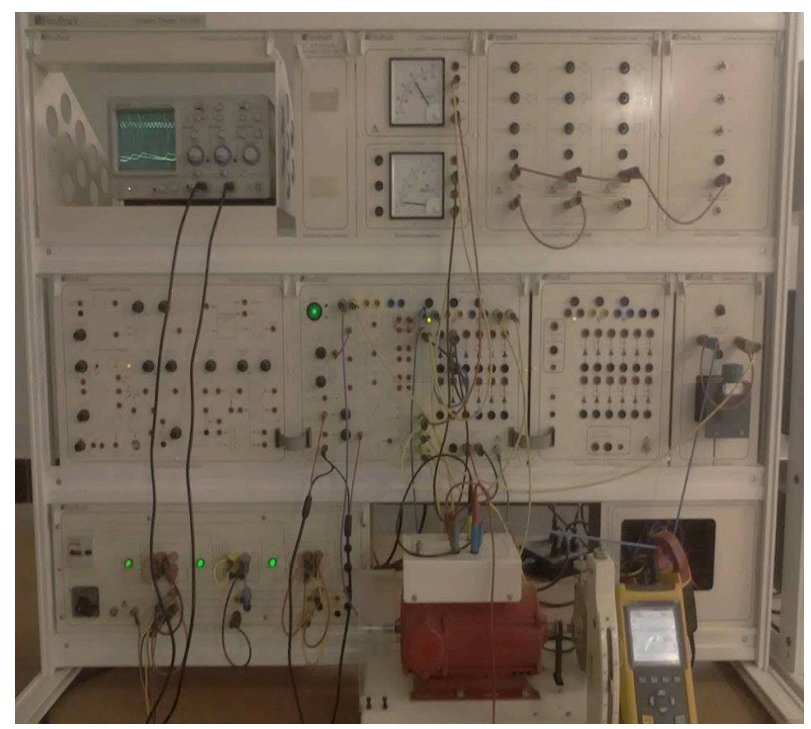

Figure 6. DC motor with patched controlled panel.

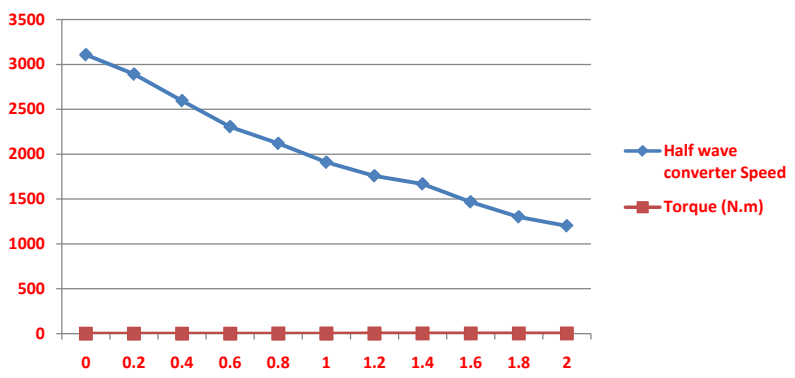

Figure 7. Speed-Torque characteristics of single phase half wave converter. 


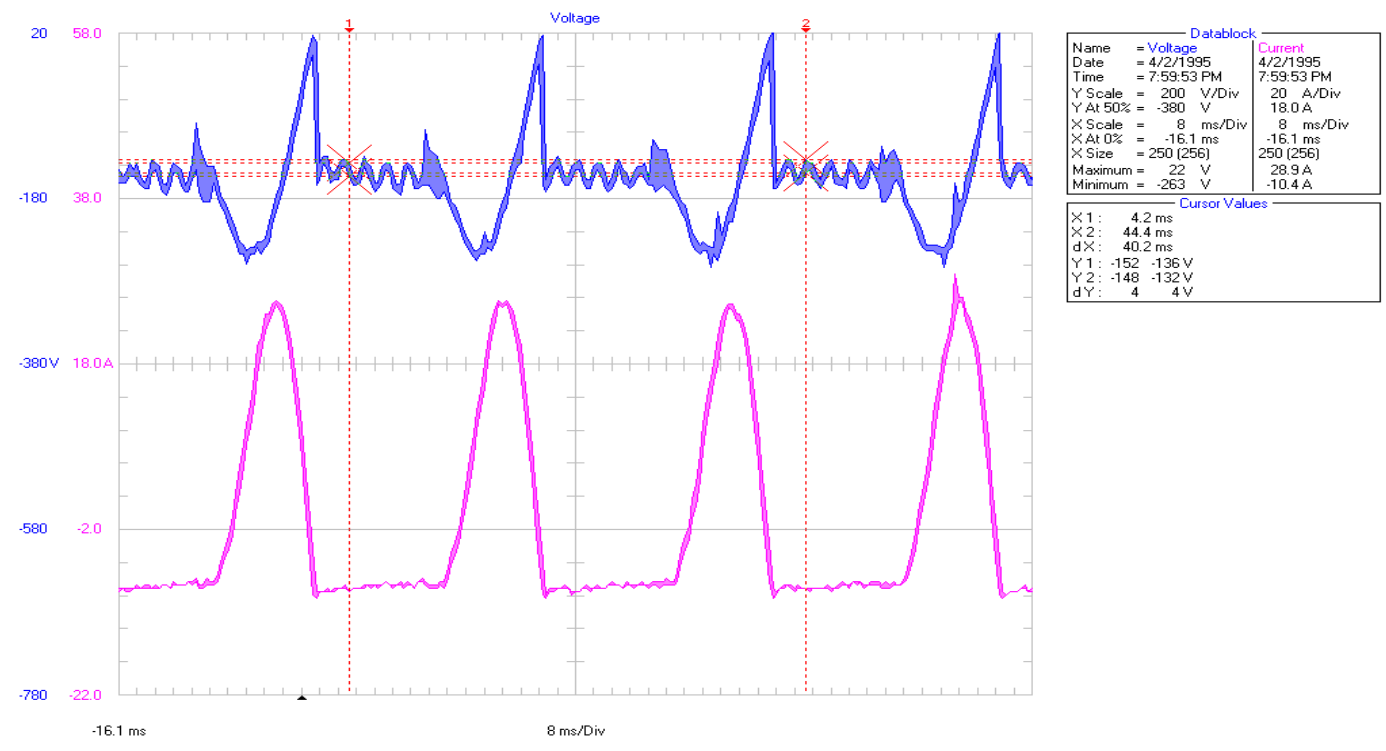

Figure 8. Armature current and armature voltage at full load torque at half wave converter.

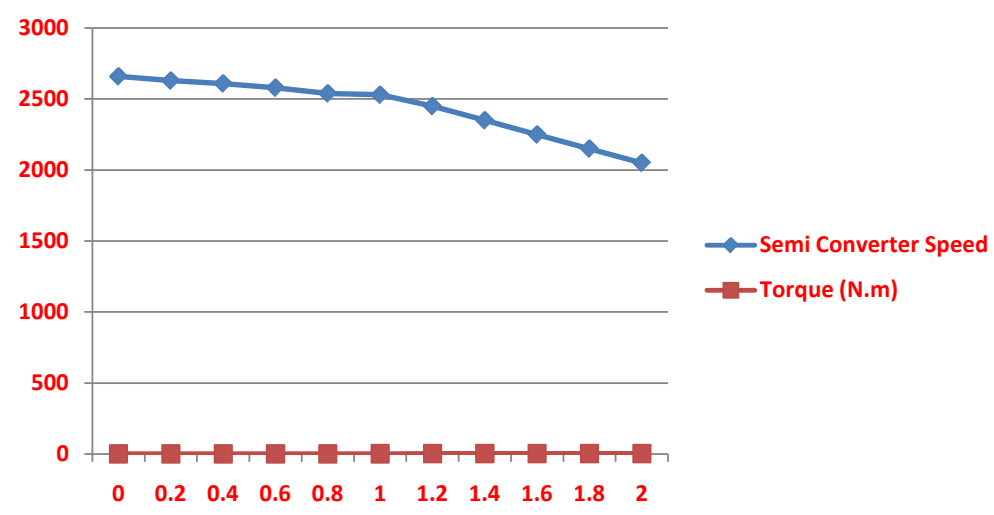

Figure 9. Speed-Torque characteristics of single phase semi converter.

Table 1. Speed and armature voltage on different torque values by using half wave converter.

\begin{tabular}{cccc}
\hline S. NO. & $\begin{array}{c}\text { Half Wave } \\
\text { Speed (rpm) }\end{array}$ & $\begin{array}{c}\text { Torque } \\
(\text { N.m) }\end{array}$ & Armature Voltage \\
\hline 1 & 3106 & 0 & 237 \\
2 & 2890 & 0.2 & 222 \\
3 & 2594 & 0.4 & 201 \\
4 & 2304 & 0.6 & 183.6 \\
5 & 2118 & 0.8 & 167.6 \\
6 & 1908 & 1 & 154.6 \\
7 & 1757 & 1.2 & 143 \\
8 & 1667 & 1.4 & 133 \\
10 & 1467 & 1.6 & 125 \\
11 & 1300 & 1.8 & 121 \\
\hline
\end{tabular}




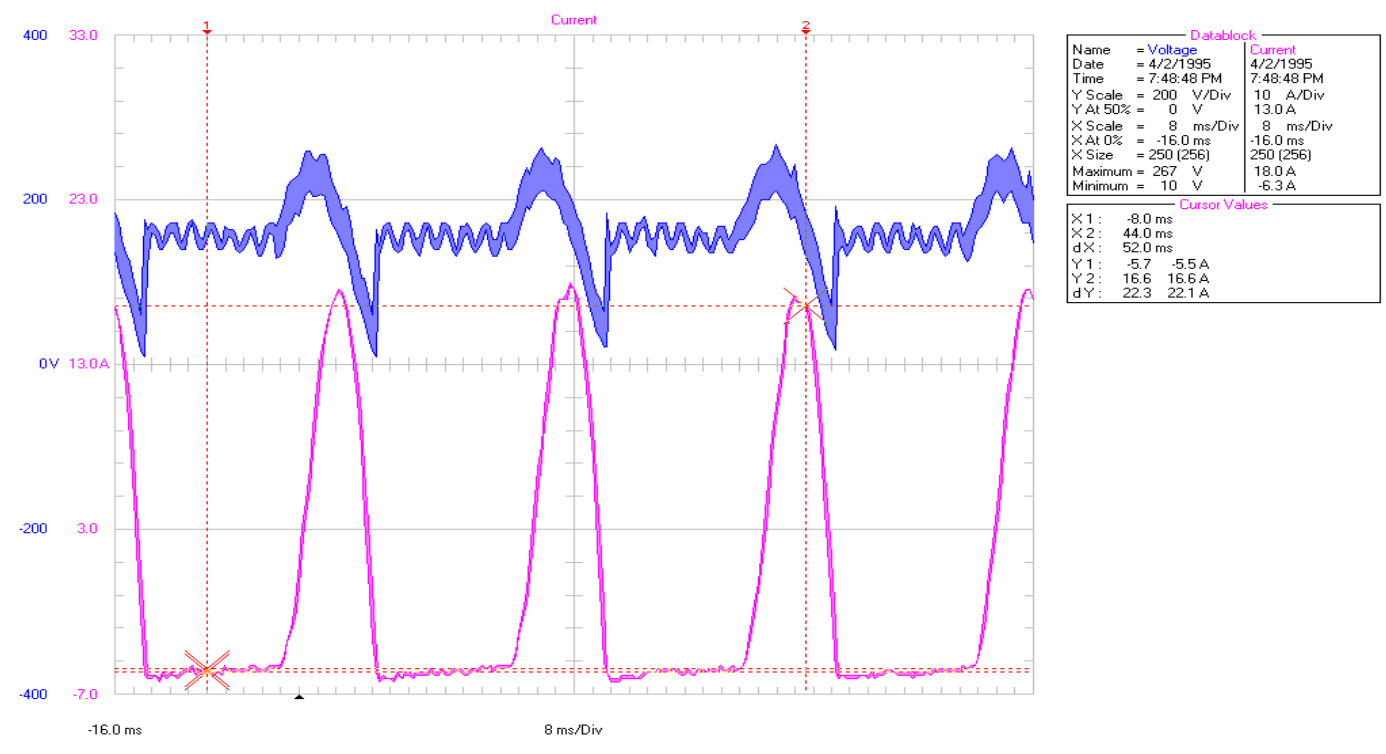

Figure 10. Armature current and armature voltage at full load torque at semi converter.

Table 2. Speed and armature voltage on different torque values by using semi wave converter.

\begin{tabular}{cccc}
\hline S. No. & $\begin{array}{c}\text { Semi Wave } \\
\text { Speed (rpm) }\end{array}$ & $\begin{array}{c}\text { Torque } \\
(\text { N.m) }\end{array}$ & Armature Voltage \\
\hline 1 & 2660 & 0 & 207 \\
2 & 2630 & 0.2 & 200 \\
3 & 2610 & 0.4 & 199 \\
4 & 2580 & 0.6 & 197 \\
5 & 2540 & 0.8 & 194 \\
6 & 2530 & 1 & 189 \\
7 & 2450 & 1.2 & 180 \\
9 & 2350 & 1.4 & 170 \\
10 & 2250 & 1.6 & 168 \\
11 & 2150 & 1.8 & 164 \\
\hline
\end{tabular}

rent will effect on linearity of DC motor torque but comparatively it is observed that in semi converter has less discontinuous current and smaller non-linearity.

In Figure 11, speed-torque characteristics of DC motor shown by using the Table 3, when torque on DC motor increases the speed of DC motor decreases, also in Figure 12 wave forms of armature voltage and armature current is shown it is clear view of discontinuous in armature current due to this discontinuous of armature current will effect on linearity of DC motor torque.

It is comparatively shown in Figure 13 by using the Table 4 in which clearly shown that which power converter is better than other.

\section{Conclusion}

This paper deals with the experimental and comparative analysis of AC/DC power semiconductor converters (i.e. half wave converter, semi converter and full wave converter) with study of speed-torque characteristic of the DC motor for armature current and torque mode. This study is performed in the laboratory of the Quaid-E-Awam 


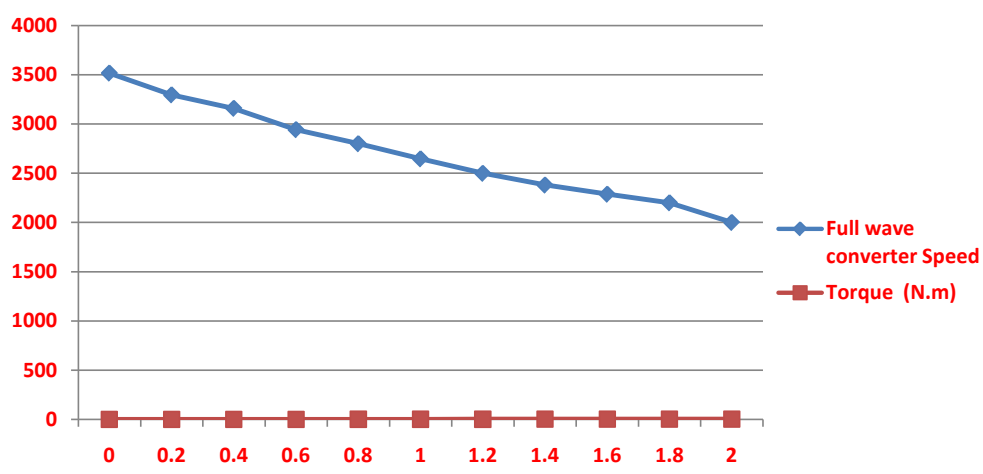

Figure 11. Speed-Torque characteristics of single phase full wave converter.

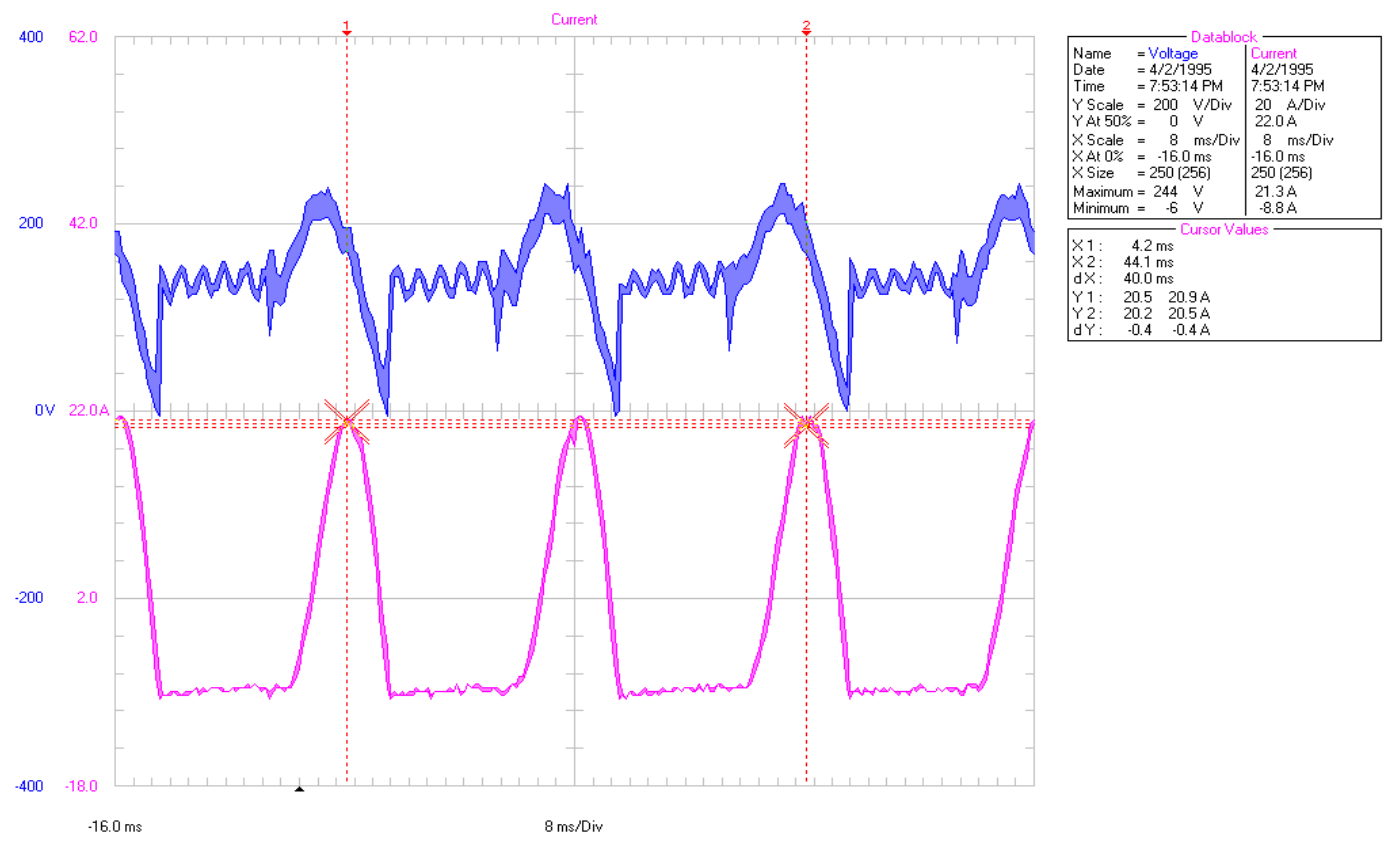

Figure 12. Armature current and armature voltage at full load torque at full wave converter.

Table 3. Speed and armature voltage on different torque values by using full wave converter.

\begin{tabular}{cccc}
\hline S. No. & Full Wave Speed (rpm) & Torque (N.m) & Armature Voltage \\
\hline 1 & 3517 & 0 & 269 \\
2 & 3296 & 0.2 & 251 \\
3 & 3159 & 0.4 & 237 \\
4 & 2943 & 0.6 & 230 \\
5 & 2800 & 0.8 & 216 \\
6 & 2646 & 1 & 208 \\
7 & 2499 & 1.2 & 198 \\
9 & 2380 & 1.4 & 112 \\
10 & 2287 & 1.6 & 184 \\
11 & 2200 & 1.8 & 170 \\
\hline
\end{tabular}




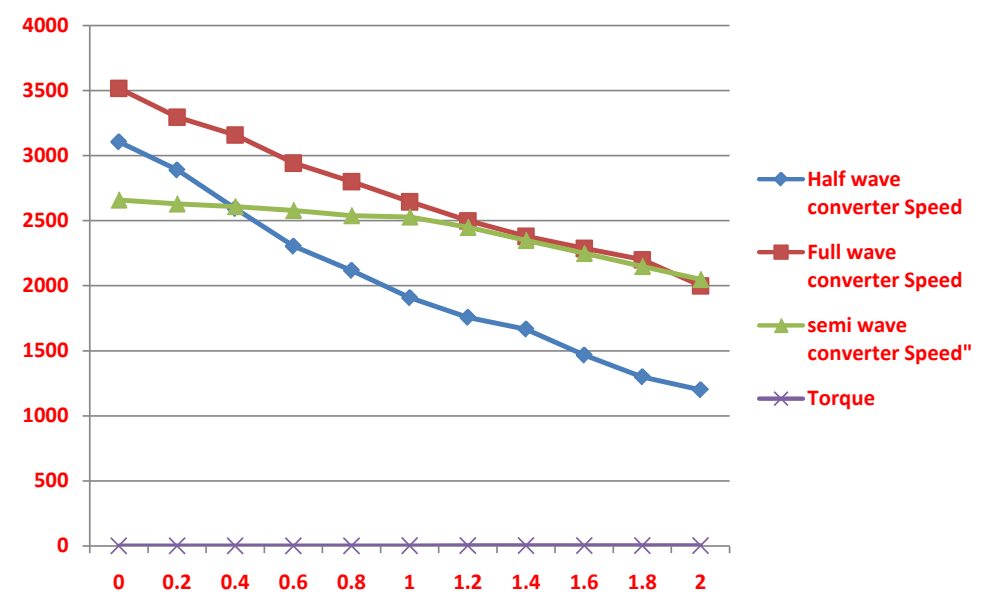

Figure 13. Speed-Torque characteristics of half, semi and full converters.

Table 4. Comparative data of speed-torque on different power converters.

\begin{tabular}{ccccc}
\hline S.No. & $\begin{array}{c}\text { Half Wave } \\
\text { Speed (rpm) }\end{array}$ & $\begin{array}{c}\text { Full Wave } \\
\text { Speed (rpm) }\end{array}$ & $\begin{array}{c}\text { Semi } \\
\text { Speed (rpm) }\end{array}$ & $\begin{array}{c}\text { Torque } \\
\text { Speed (rpm) }\end{array}$ \\
\hline 1 & 3106 & 3517 & 2660 & 0 \\
2 & 2890 & 3296 & 2630 & 0.2 \\
3 & 2594 & 3159 & 2610 & 0.4 \\
4 & 2943 & 2580 & 0.6 \\
5 & 2304 & 2800 & 2540 & 0.8 \\
6 & 2118 & 2646 & 2530 & 1 \\
7 & 1908 & 2499 & 2450 & 1.2 \\
10 & 1757 & 2380 & 2350 & 1.4 \\
11 & 1667 & 2287 & 2250 & 1.6 \\
\hline
\end{tabular}

University of Engineering Sciences and Technology, Nawabshah, Sindh, Pakistan. The DC motor has been taken for experimental test on various torque (mechanical load) applied on DC motor ranging from 0 to $2 \mathrm{Nm}$; it has been observed that discontinuous in armature current due to each converter. This inferior property of power converters will effect on DC motor torque, which is not acceptable for heavy load. It is concluded that the semi power converter has less non linearity in the torque due to small discontinuity of the armature current as comparing with half wave and full wave power converters.

\section{References}

[1] Enany, M.A. (2010) Effects of Single Phase AC/DC Converter Drive on the Torque-Speed Characteristic of DC Motor. Proceedings of the 14th International Middle East Power Systems Conference (MEPCON'10), Cairo University, Egypt, 19-21 December 2010, Paper ID: 284.

[2] Chapman, S.J. (1998) Electric Machinery Fundamentals. WCB/McGraw-Hill, New York. Daniels, W.M. and Shaffer, A.R. (1998) Re-Inventing the Electrical Machines Curriculum. IEEE Transactions on Education, 41, 92-100.

[3] Mohan, N. (2000) Electric Drives: An Integrative Approach. University of Minnesota Printing Services.

[4] Nedeljkovic, M. and Stojiljkovic, Z. (2003) Fast Current Control for Thyristor Rectifiers. IEE Proceedings-Electric 
Power Applications, 150, 636-638.

[5] Consoli, A., Cacciato, M., Testa, A. and Gennaro, F. (2004) Single Chip Integration for Motor Drive Converters with Power Factor Capability. IEEE Transactions on Power Electronics, 19, 1372-1379. http://dx.doi.org/10.1109/TPEL.2004.836636

[6] Vadapalli, V.R. (2015) Speed Control of D.C. Motor Using Chopper. International Journal of Electrical and Electronics Research, 3, 289-295.

[7] Ahmed, A. (2013) Comparative Study of Speed Control of D.C. Motor Using PI, PID, and Fuzzy Controller. International Journal of Advanced Research in Computer and Communication Engineering, 2.

[8] Gupta, R. (2012) Thyristor Based Speed Control Techniques of DC Motor: A Comparative Analysis. International Journal of Scientific and Research Publications, 2, 2250-3153. 